\title{
An HPLC Method for the Determination of Saxagliptin in Human Plasma with Fluorescence Detection
}

\section{Serife Evrim Kepekci Tekkeli, Mustafa Volkan Kızıltaş, Demet Dinçel}

Bezmialem Vakif University, Faculty of Pharmacy, Department of Analytical Chemistry, 34093, Fatih- IstanbulTurkey

evrimkepekci@yahoo.com

mustafavolkankz@gmail.com

dinceldmt@hotmail.com

\section{ABSTRACT}

A sensitive and selective HPLC method with fluorometric detection was developed for the determination of saxagliptin (SGX) in human plasma and applied to a pharmacokinetic study. SGX was precolumn derivatized with fluorescamine, and the fluorescent derivative was separated on an RP C18 column using a mobile phase composed of acetonitrile-10 mM orthophosphoric acid by isocratic elution with flow rate of $1.3 \mathrm{ml} / \mathrm{min}$. The method was based on the measurement of the derivative using fluorescence detection at $378 \mathrm{~nm}$, with excitation at $463 \mathrm{~nm}$. The calibration curve was linear over the range of $3.0-100.0 \mathrm{ng} / \mathrm{ml}$. LOD and LOQ were found to be 0.15 and $0.5 \mathrm{ng} / \mathrm{ml}$, respectively. Intraday and interday RSD values were less than $2.84 \%$. The plasma concentration-time profile and pharmacokinetic parameters such as $\mathrm{AUC}_{0-\mathrm{t}}$, $\mathrm{AUC}_{0-\infty}, \mathrm{C}_{\max }, \mathrm{t}_{\max }, \mathrm{t}_{1 / 2}$, were calculated according to the assays.

\section{Indexing terms/Keywords}

Fluorescamine; HPLC; pharmacokinetic; pre-column derivatization; saxagliptin; plasma

\section{Academic Discipline And Sub-Disciplines}

Analytical chemistry

\section{SUBJECT CLASSIFICATION}

Pharmaceutical analytical chemistry

\section{TYPE (METHOD/APPROACH)}

Pharmaceutical analysis

\section{Council for Innovative Research}

Peer Review Research Publishing System

Journal: Journal of Advances in Chemistry

Vol. 5, No. 3

editor@cirworld.com

www.cirworld.com, member.cirworld.com 


\section{INTRODUCTION}

Saxagliptin (SGX), (1S, 3S, 5S) - 2 - [(2S) - 2 - amino - 2 - (3 - hydroxy - 1 - adamantyl) acetyl] - 2 - azabicyclo [3.1.0] hexane - 3 - carbonitrile, is a widely used drug substance for treatment of type 2 diabetes mellitus [1]. It is a reversible dipeptidyl peptidase 4 (DPP4) inhibitor. DPP4 inhibitors facilitate glucose-dependent insulin secretion. Moreover, glucagon release decreases, gastric emptying slows and appetite reduces by increasing the levels of active glucagon-like peptide 1 (GLP-1) [2]. To date two liquid chromatography with tandem mass spectrometry (LC-MS/MS) methods were developed and validated for SGX in plasma, one of them describes the assay for human plasma [3] and the other one is for rat plasma [4]. However, they are fairly sensitive, accurate and precise methods, a simplier and more cost reduced method is required for the analysis of SGX in human plasma.

For this aim an HPLC method with fluorimetric detection has been developed and validated for human plasma assays. The plasma levels of the drug was monitorized in order to investigate the pharmacokinetic parameters. The fluorimetric detection is provided by a pre-column derivatization process with a fluorogenic reagent; fluorescamine, which is frequently preffered because of its basic derivatization procedure, fast reactivity and high sensitivity [5],[6],[7],[8]. The derivatization reaction is shown in Figure 1.
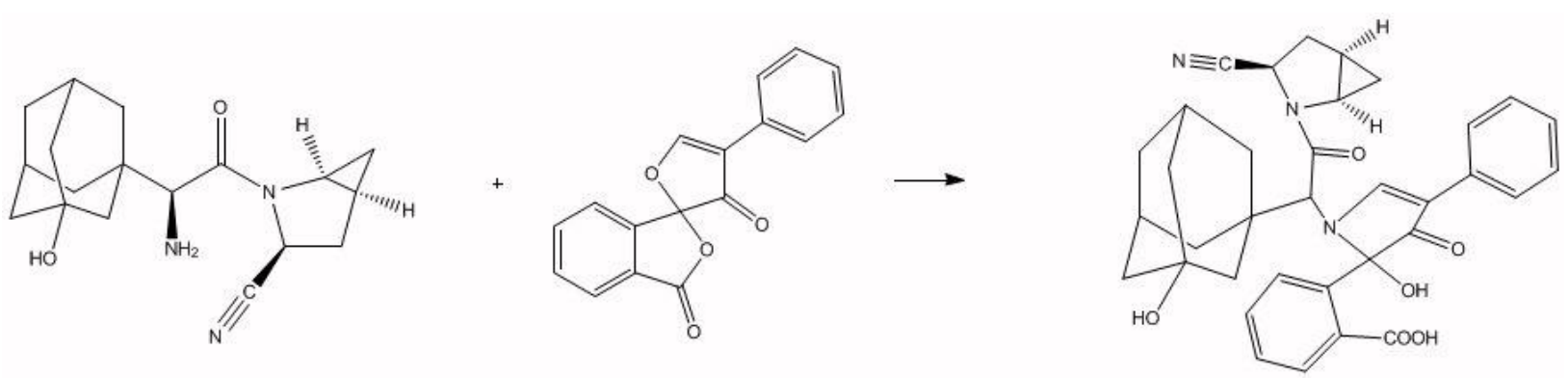

Saxagliptin

Fluorescamine

Figure 1. The derivatization reaction process between SGX and fluorescamine

\section{MATERIALS AND METHODS}

\section{Chemicals and Reagents}

SGX was supplied from Shanghai Yingxuan Pharmaceutical Science \& Technology (China), Onglyza® tablets containing $5 \mathrm{mg}$ SGX were purchased from local drug store. Acetonitrile, orthophosphoric acide (HPLC grade) and hexane, isopropanol (analytical grade) were supplied from Merck (Darmstadt, Germany). Fluorescamine was obtained from Sigma (MO, USA). Water was purified by Human (Japan) ultrawater purification system.

\section{Solutions}

A stock solution of SGX $(0.1 \mathrm{mg} / \mathrm{ml})$ was prepared in water and diluted with water to give standard solutions of $0.05,0.5$, and $1 \mu \mathrm{g} / \mathrm{ml}$.

Borate buffer was prepared by dissolving $0.620 \mathrm{~g}$ boric acid and $0.750 \mathrm{~g}$ potassium chloride in $100 \mathrm{ml}$ water. The $\mathrm{pH}$ level was adjusted to 8.5 with $0.1 \mathrm{M}$ sodium hydroxide solution, and the volume was made up to $200 \mathrm{ml}$ with water. All solutions except fluorescamine, were stored at $4^{\circ} \mathrm{C}$ and were stable at least for 2 weeks. Fluorescamine solution was freshly prepared in acetone at $1 \mathrm{mg} / \mathrm{ml}$ concentration.

\section{Instrumentation}

The HPLC analyses were performed on a Shimadzu (Japan) LC 20 liquid chromatograph which consisted of a LC-20AT pump, SIL AT-HT autosampler part, a SPD-20A HT UV detector, which was set at $378 \mathrm{~nm}$ for excitation and 463 for emission nm and CTO $10 \mathrm{AC}$ column oven were used. Chromatographic separation was achieved isocratically at $40^{\circ} \mathrm{C}$ on a GL Sciences (Japan) C18 (ODS) column with the dimensions; $4.6 \mathrm{~mm}$ I.D, $150 \mathrm{~mm}$ length and $5 \mu \mathrm{m}$ particle size. The mobile phase was acetonitrile-10 mM orthophosphoric acid $(\mathrm{pH} 2.4)$ containing with a flow rate of $1.3 \mathrm{ml} / \mathrm{min}$.

\section{Optimization Studies for Experimental Parameters}

The different experimental parameters affecting the development of the reaction product were carefully studied and optimized. Such factors were changed individually while others were kept constant. These factors were: $\mathrm{pH}$, concentration of the reagent, temperature and heating period, acetone-water ratio in the reaction medium. According to the results precolumn derivatization procedure was conducted. 


\section{Sample Preparation and General Procedure}

$5 \mathrm{ml}$ venous blood samples were collected from peripheral veins of a volunteer (informed consent form was obtained according to ethical commitee approval) into tubes containing disodium EDTA and centrifuged at $4500 \times \mathrm{g}$ for $10 \mathrm{~min}$. The resultant plasma samples were stored at $-20^{\circ} \mathrm{C}$. To extract the drug from the plasma samples, $0.5 \mathrm{ml}$ plasma was alkalinized with $250 \mathrm{ml} 0.1 \mathrm{M} \mathrm{NaOH}$, and the solution was then extracted into $3 \mathrm{ml}$ of hexane-propanol (2:1, v/v). The contents were mixed with vortex mixer at moderate speed for $5 \mathrm{~min}$ and centrifuged at $4500 \times \mathrm{g}$ for $3 \mathrm{~min}$. The aqueous layer was discarded. The organic layer was evaporated to dryness under a stream of nitrogen at $40^{\circ} \mathrm{C}$. To the residue, 1 $\mathrm{ml}$ water, $500 \mu \mathrm{l} \mathrm{pH} 8.5$ borate buffer and $500 \mu \mathrm{l} 1 \mathrm{mg} / \mathrm{ml}$ fluorescamine solution were added. The solution was vigorously mixed with a vortex mixer for $30 \mathrm{sec}$. and $20 \mu \mathrm{l}$ of the derivatized sample was injected into the HPLC system.

\section{RESULTS}

\section{Derivatization and Separation}

Reaction conditions of SGX with fluorescamine were investigated. The optimum reaction time, temperature, $\mathrm{pH}$, buffer type, proportions of acetone-water, and mole ratio of fluorescamine/SGX were determined.

\section{Effect of pH}

The reaction of fluorescamine with primary amines has been shown to be strongly $\mathrm{pH}$ dependent [9]. It was noticed that the fluorescence emission was developed only in alkaline medium by using borate buffer 5-8 and therefore, study of the $\mathrm{pH}$ was restricted to within the range 7-11 using borate buffer. Maximum absorbance was obtained at $\mathrm{pH} 8.5$.

\section{Effect of time and temperature}

In order to determine the optimum temperature and time required for the reaction, the derivatization reaction was carried out at different temperatures and durations. It was found that the fluorophore was formed immediately at room temperature. It is an advantage that fluorescamine does not require any heating procedure or long reaction time.

\section{Effect of fluorescamine concentration}

The effect of fluorescamine concentration on the derivatization reaction was studied. It was found that $1.3 \times 10-3 \mathrm{mmol}(0.5$ $\mathrm{ml}$ of $1 \%(\mathrm{w} / \mathrm{v})$ ) fluorescamine solution was sufficient to obtain maximum fluorescence. The effects of these parameters on fluorescence intensity of the derivatives are shown in Figure 2.

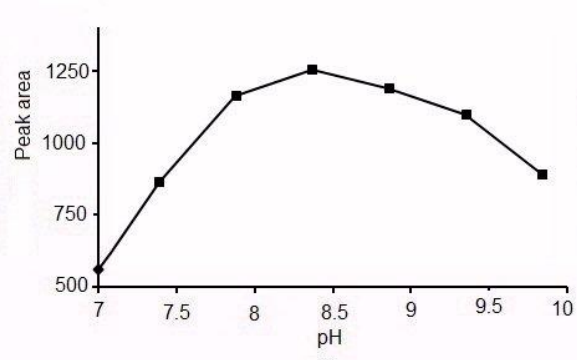

(a)
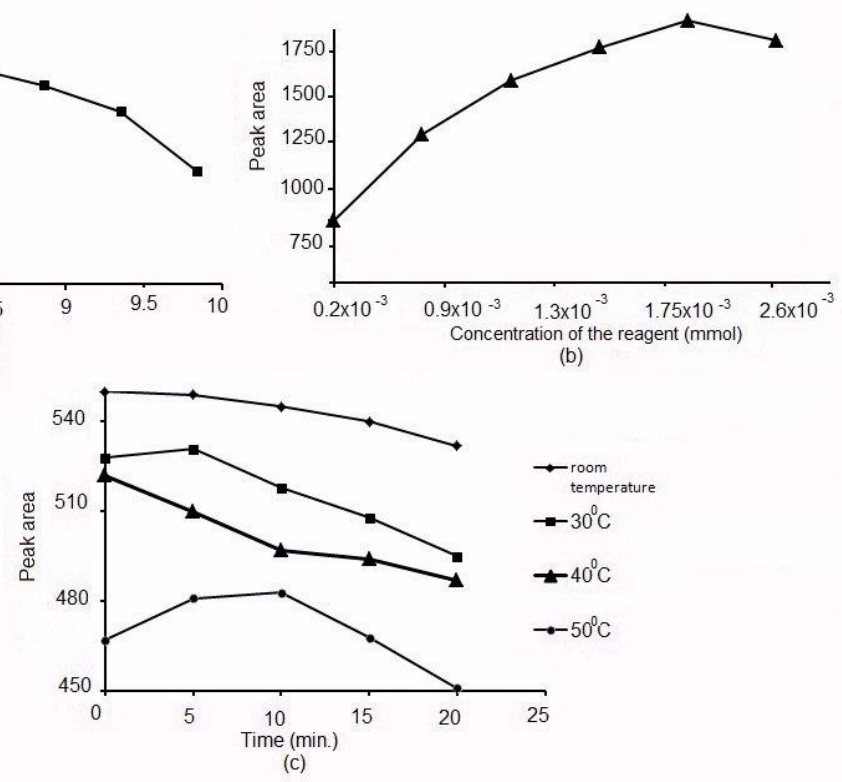

Figure 2. a. The effect of $\mathrm{pH}$ on the development of the reaction product of SGX with fluorescamine.

b. The effect of fluorescamine concentration on the development of the reaction product of SGX with fluorescamine.

c. The effect of temperature and time of heating on the reaction between SGX with fluorescamine. 


\section{Effect of acetone to water ratio in derivatization medium}

Different volumes of acetone and water, were trialed where the concentrations of drug, buffer and fluorescamine solutions were kept constant. The maximum peak area was observed by using a ratio of acetone to water as 1:1.

\section{Stoichiometry of the reaction}

The molar ratio of fluorescamine to SGX in the reaction mixture was studied according to Job's method of continuous variation [10]. Utilizing equimolar solutions of SGX and fluorescamine, the reaction stoichiometry was found to approximate to a 1:1 ratio (reagent/drug). According to peak areas, it is correct to say that all of the reagent is consumed, and there is no shortfall or excess of the reagent in this stoichiometric ratio.

Upon testing derivatization reactions, all solutions were injected into the HPLC system and peak areas were measured to find the optimal conditions. Derivatives, prepared under the above mentioned conditions, remained stable for at least $24 \mathrm{~h}$.

A good separation of the derivatives and endogenous compounds of plasma was obtained using an isocratic elution system and RP-HPLC as described above. Representative chromatograms of the blank plasma and plasma samples spiked with SGX $(50 \mathrm{ng} / \mathrm{ml})$ are shown in Figure $3 a$ and b, respectively. No interference was detected with the plasma constituents. The retantion time of SGX is about $3.5 \mathrm{~min}$.
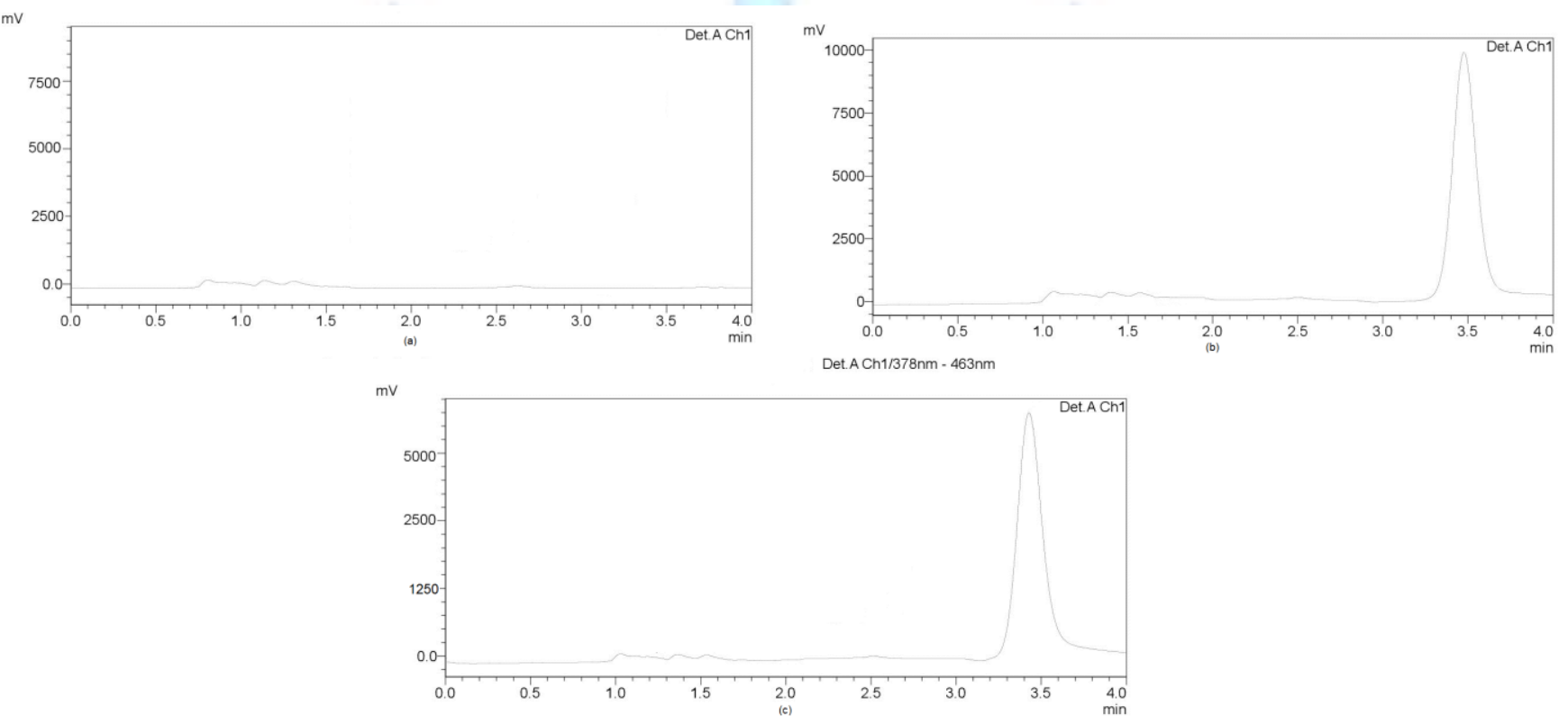

Figure 3. Chromatograms obtained from an extract of (a) human blank plasma (b) human blank plasma spiked with $50 \mathrm{ng} / \mathrm{mL}$ SGX (c) plasma samples from the volunteer after $2 \mathrm{~h}$ after a single oral dose of $5 \mathrm{mg}$ drug containing $23.5 \mathrm{ng} / \mathrm{mL}$ SGX

\section{Validation of the method}

Validation of the method was carried out according to the following guidelines given by the International Conference on Harmonization (ICH) [11].

\section{Calibration and sensitivity}

Calibration curves were obtained using linear least-squares regression analysis by plotting of peak areas of the derivatives versus the corresponding SGX concentrations. The mean equation of the calibration curve $(n=6)$ obtained from five points was: $y=0.123 x+0.3472$ (correlation coefficient $=0.9996$ ) where y represents peak area of SGX-fluorescamine derivative and $x$ represents the concentration of $S G X$.

\section{The limit of detection (LOD) and limit of quantitation (LOQ)}

$L O D$ and $L O Q$ were determined using the formula: $L O D$ or $L O Q=k S D a / b$, where $k=3$ for $L O D$ and 10 for $L O Q, S D a$ is the standard deviation of the intercept, and $b$ is the slope. The parameters for the analytical performance of the proposed method are summarized in Table 1. 
Table 1. Analytical parameters of the method

\begin{tabular}{ll}
\hline Parameters & Method \\
& \\
\hline Concentration range $^{\mathrm{a}}(\mathrm{ng} / \mathrm{ml})$ & $3-100$ \\
Regression equation $^{\mathrm{b}}$ & \\
Intercept $\pm \mathrm{SD}$ & $0.3472 \pm 0.097$ \\
Slope $\pm \mathrm{SD}$ & $0.123 \pm 0.024$ \\
Correlation coefficient $\left(\mathrm{r}^{2}\right)$ & 0.9996 \\
LOD $(\mathrm{ng} / \mathrm{ml})$ & 0.15 \\
LOQ $(\mathrm{ng} / \mathrm{ml})$ & 0.5
\end{tabular}

${ }^{\text {a }}$ Average of six determinations

${ }^{\mathrm{b}} y=x C+\mathrm{b}$ where $C$ is the concentration in $\mathrm{ng} / \mathrm{ml}$ and $y$ is the peak area

\section{Accuracy, precision and recovery}

Accuracy and precision were assessed by determination of the QC samples at three concentration levels, (10.0, 50.0, and $75.0 \mathrm{ng} / \mathrm{ml}$ ) that can be classified as low, medium and high concentrations were prepared. The accuracy was expressed by recovery values and RME and the precision by RSD. The absolute recovery of SGX from plasma was examined by extraction and derivatization of spiked plasma samples and comparison with peak areas obtained after derivatization of the same amounts of aqueous unextracted SGX solutions. The mean absolute recovery of SGX were of $89.17 \%$. The relative recovery was calculated as $97.37 \%$ by the comparison of the amounts that is added on to plasma and measured by the calibration curve.

Six replicates of samples at each concentration were assayed on the same day for intraday and on six different days for interday precision and accuracy. The RSD values of both intraday and interday assays were all less than $2.92 \%$. According to all these results summarized in Table 2 good precision and accuracy were observed.

Table 2. Accuracy and precision of the method

\begin{tabular}{llllll}
\hline $\begin{array}{l}\text { Added } \\
\text { concentration } \\
(\mathrm{ng} / \mathrm{ml})\end{array}$ & $\begin{array}{l}\text { Found } \\
\text { concentration } \\
(\mathrm{ng} / \mathrm{ml}) \\
\left(\text { Mean } \pm \mathrm{SD}^{1}\right)\end{array}$ & $\begin{array}{c}\text { Recovery } \\
(\%)\end{array}$ & $\begin{array}{l}\text { RSD of } \\
\text { recovery }\end{array}$ & $\begin{array}{l}\text { RSD of } \\
\text { intraday } \\
\text { variation }\end{array}$ & $\begin{array}{l}\text { RSD of } \\
\text { interday } \\
\text { variation }\end{array}$ \\
\hline 10.00 & $9.53 \pm 0,09$ & 95.30 & 0.66 & 2.80 & 2.92 \\
50.00 & $48.86 \pm 0,42$ & 97.72 & 1.25 & 2.25 & 2.76 \\
75.00 & $74.33 \pm 0,35$ & 99.10 & 1.45 & 1.67 & 1.72 \\
& & & & & \\
\hline
\end{tabular}

\section{Robustness}

Robustness was assessed by changing the flow-rate, column oven temperature and acetonitrile and water phase contents of the mobile phase. The mobile phase proportions were changed from 30:70 (acetonitrile-acidic solution) to 35:65 and 25:75; column temperature was changed from $40^{\circ} \mathrm{C}$ to $35^{\circ} \mathrm{C}$ and $40^{\circ} \mathrm{C}$; and the flow rate was changed from 1.3 to 0.8 and $1.8 \mathrm{ml} / \mathrm{min}$. These changes had no significant effect on peak areas.

\section{Stability}

The effects of freezing and thawing on SGX concentrations were studied using spiked SGX plasma standards at 10, 50, $75 \mathrm{ng} / \mathrm{ml}$, which were subjected to four freeze-thaw cycles before analysis. The stability of derivatives in spiked plasma stored at room temperature for $24 \mathrm{~h}$ and $-20^{\circ} \mathrm{C}$ for 2 weeks was evaluated, as well. Stock solutions of SGX were stable at least for 30 days when stored at $-20^{\circ} \mathrm{C}$. After 30 days no decrease was observed in the concentration of SGX in plasma. 
Derivatized solutions were found to be stable for 4 days, if the samples were kept at $4^{\circ} \mathrm{C}$ using a sample cooler, 1 day at room temperature.

\section{Application of the Method to Pharmacokinetic Analysis}

The proposed method was applied to the determination of the drug substance in plasma for the pharmacokinetic studies. A healthy 29 year-old male volunteer was administered a single oral dose of SGX $(5 \mathrm{mg})$. Approximately, $5 \mathrm{ml}$ venous blood samples were collected prior to dosage and 1, 2, 3, 4, 6, 8, and 10 hours afterwards on the first day. For the following days, blood samples were collected once a day for 10 days. The blood samples were processed to plasma as described above. Figure $3 \mathrm{c}$ shows a chromatogram of the plasma sample obtained $2 \mathrm{~h}$ after the single oral dose of $5 \mathrm{mg}$ SGX from the volunteer. The samples were stored at $-20^{\circ} \mathrm{C}$ until analysis.

Pharmacokinetic analysis was carried out using standard methods. Area under the plasma concentration-time curves $\left(\mathrm{AUC}_{0-96}, \mathrm{AUC}_{0-\infty}\right)$ were calculated using the TOPFIT 2.0 pharmacokinetic and pharmacodynamic data analysis system [12]. A plasma concentration-time curve of SGX after an oral administration of a single dose of $5 \mathrm{mg}$ of drug is shown in Figure 4. Pharmacokinetic parameters, which are given in Table 3, are identical to those previously found [2],[13].

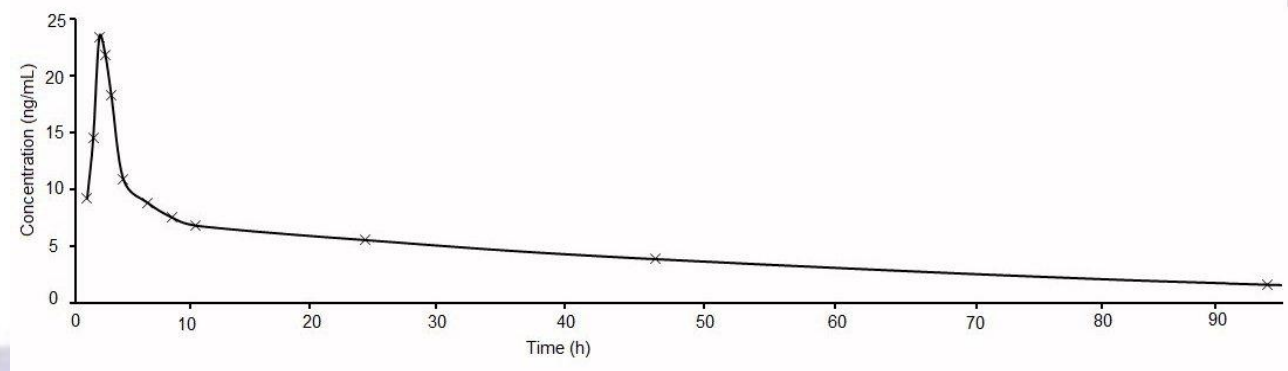

Figure 4. Pharmacokinetic curve of SGX between 0 and 96 hours after administration of $5 \mathrm{mg}$ oral dose

Table 3. Pharmacokinetic parameters of sgx after administration of single oral dose of $5 \mathrm{mg}$

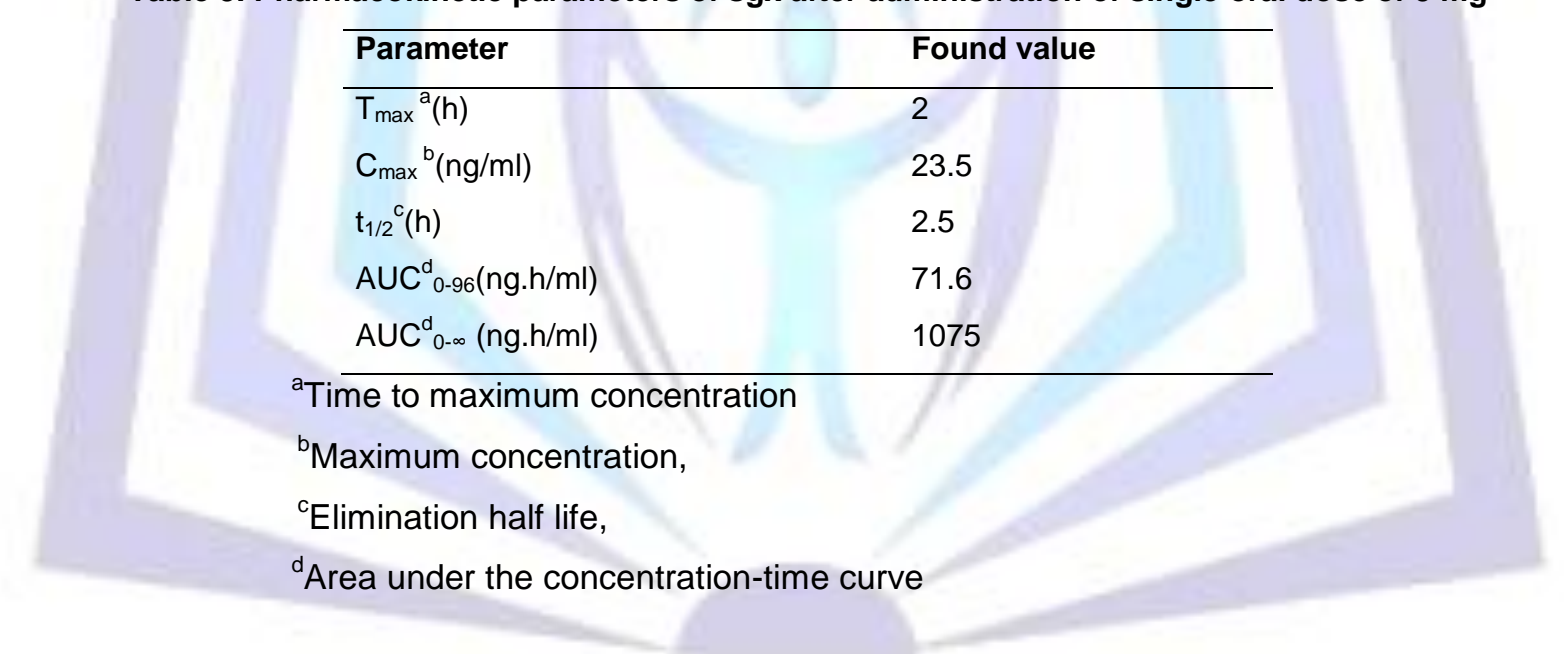

\section{DISCUSSION}

The main advantage of the proposed method is the ability to determine SGX in human plasma with a lower cost than other techniques [3],[4]. It is difficult to apply those MS methods for routine analysis, because they require high cost equipment and sophisticated operator which are not generally available in routine laboratories. The proposed method is very sensitive with a $0.5 \mathrm{ng} / \mathrm{ml} \mathrm{LOQ}$ value. This is very important for SGX because the drug has very low plasma concentrations in the pharmacokinetic studies. The other advantages are related to simplicity of the derivatization process and extraction procedure from plasma with high recovery values. Generally, fluorogenic derivatization require heat and longer time. In this method there is not any time consuming procedures. The retantion time of the drug substance is about 3.5 min, which shows the duration of the analyse is also very short. The presented method can certainly be used for bioequivalence and bioavailability investigations and routine analysis of the drug in plasma. 


\section{ACKNOWLEDGMENTS}

The study protocol was approved by the Clinical Trials Ethics Commitee of Bezmialem Vakif University.

\section{REFERENCES}

[1] Brunton, L.L., Chabner, B.A., Knollmann, .B.C.,1993. Goodman and Gilman's The Pharmacological Basis of Therapeutics.

[2] Kania, S.D., Gonzalvo, J.D. and Weber, A.Z. 2011. Saxagliptin: A Clinical Review in the Treatment of Type 2 Diabetes Mellitus. Clin. Ther. 33(8), 1005-1022.

[3] Xu, X.S., Demers, R., Gu. H, Christopher, L.J., Su, H., Cojocaru, L. and Boulton, D. W, et al. 2012. Liquid chromatography and tandem mass spectrometry method for the quantitative determination of saxagliptin and its major pharmacologically active 5-monohydroxy metabolite in human plasma: Method validation and over coming specific and non-specific binding at low concentrations. J. Chromatogr. B Analyt. Technol. Biomed. Life Sci. 77(86), 889-890.

[4] Gao, J.W., Yuan, Y.M., Lu, Y.S. and Yao, M.C. 2012. Development of a rapid UPLC-MS/MS method for quantification of saxagliptin in rat plasma and application to pharmacokinetic study. Biomed. Chromatogr. 26(12), 1482-1487.

[5] Cesur, N., Apak, T.I., Aboul-Enein, H.Y. and Ozkirimli, S. 2002. LC determination of aminoglutethimide enantiomers as dansyl and fluorescamine derivatives in tablet formulations. J. Pharm. Biomed. Anal. 15(28), 487-492.

[6] Sagirli, O. and Ersoy, L. 2004. An HPLC method for the determination of lisinopril in human plasma and urine with fluorescence detection. J. Chromatogr. B Analyt. Technol. Biomed. Life Sci. 809(1), 159-165.

[7] Huang, X. and Hernick, M. 2011. Fluorescence-based assay for measuring N-acetyl-1-D-myo-inosityl-2-amino-2-

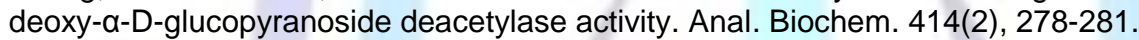

[8] Eggenreich, K., Zach. E., Beck, H. and Wintersteiger, R. 2004. Determination of 4-amino-m-cresol and 5-amino-ocresol by high performance liquid chromatography and fluorescence derivatization using fluorescamine. J. Biochem. Biophys. Methods 61(1-2), 35-46.

[9] Stein, S., Bohlen, P., Stone, J., Dairman, W. and Undenfriend, S. 1973. Amino acid analysis with fluorescamine at the picomole level. Arch. Biochem. Biophys. 155(1), 203-212.

[10] Job, P. 1928. Formation and stability of inorganic complexes in solution. Anal. Chem. 9, 113-203.

[11] Text on validation of analytical procedures Q2A. Technical requirements for registration of pharmaceuticals for human use. ICH, IFPM (Geneva) 2005.

[12] Heinzel G, Wolosczak R, Thomann P. Version TOPFITT 2.0 Pharmacokinetic and Pharmacodynamic Data Analysis System for the PC. VCH Publishers: Gustav- Fisher-Verlag, (Stuttgart, Germany) 1993.

[13] United States Prescribing Information for Onglyza ${ }^{\text {TM }}$ (Saxagliptin) Bristol-MyersSquibb Company andAstra Zeneca Pharmaceuticals, 2011.

\section{Author' biography with Photo}

$\begin{array}{lc}\text { Name Surname } & : \text { Şerife Evrim Tekkeli } \\ \text { Date of Birth } & : 30 \text { Ağustos } 1979 \\ \text { Title } & : \text { Assistant Prof.Dr. } \\ \text { Educational Status } & : \text { PhD }\end{array}$




\begin{tabular}{lllll}
\multicolumn{2}{c}{ Degree Department } & \multicolumn{2}{c}{ University } & \multicolumn{2}{c}{ Year } \\
BSc & Pharmacy & Istanbul University & 2001 & \\
MSc & Pharmacy-Analytical Chemistry & Istanbul University & 2003 \\
PhD & Pharmacy-Analytical Chemistry & Istanbul University & 2007
\end{tabular}

\section{Academic Titles}

$\begin{array}{lcc}\text { Assistant Prof.Dr. } & \text { Bezmialem Vakif University } & 2010-\ldots \\ \text { PhD Pharm } & \text { Istanbul University } & 2007\end{array}$

\section{Publications}

\section{Published Articles at International Journals (SCI\&SSCI\&Arts and Humanities )}

Spectrophotometric Methods for the Determination of Antidepressant Drug Paroxetine Hydrochloride in Tablets. Onal A, Kepekci SE, Oztunç A, Journal of AOAC International, 88 (2), 490-495 (2004).

Spectrophotometric Determination of Certain Antidepressants in Pharmaceutical Preparations. Onal A, Kepekci SE, Cetin SM, Ertürk S, Journal of AOAC International 89 (4), 966-971 (2006).

Isolation and analysis of bioactive diterpenoids in Salvia species (Salvia chionantha and Salvia kronenburgii) by micellar electrokinetic capillary chromatography. Oztekin N, Baskan S, Kepekci SE, Topcu G, Journal of Pharmaceutical and Biomedical Analysis, 51 (2), 439-442 (2010).

Spectrofluorimetric Methods for the Determination of Gemifloxacin in Tablets and Spiked Plasma Samples. Tekkeli Kepekci SE, Onal A, Journal of Fluorescence, DOl10.1007/S10895-010-0759-1. 21 (3), 1001-1007 (2011).

A Review of Current Methods for the Determination of Acrylamide in Food Products Tekkeli Kepekci SE, Onal A, Onal C, Food Analytical Methods, DOI 10.1007/s12161-011-9277-2. (2011).

A review of the liquid chromatographic methods for the determination of biogenic amines in foods. Armağan Onal, Serife Evrim Kepekci Tekkeli, and Cem Onal, Food Chemistry, 138(1):509-15 (2013).

A new HPLC Method For The Determination Of Memantine In Human Plasma With Fluorescence Detection, Tekkeli Kepekci SE, Ertürk S, Journal of AOAC International, 96(1), 52-55 (2013).

Spectrofluorimetric determination of tobramycin in human serum and pharmaceutical preparations by derivatization with fluorescamine. Serife Evrim Kepekci Tekkeli, Armağan Onal, Olcay Sagirli, Luminescence, DOI: DOI 10.1002/bio.2507, 2013

Development of an HPLC-UV method for the analysis of drugs used for combined hypertension therapy in pharmaceutical preparations and human plasma, Serife Evrim Kepekci Tekkeli, Journal of Analytical Methods in Chemistry, Journal of Analytical Methods in Chemistry, doi:10.1155/2013/179627, (2013)

New spectrophotometrıc and spectrofluorimetric methods for the determination of angiotensin II receptor antagonists in tablets and plasma. Serife Evrim Kepekci Tekkeli, Armağan Onal, Journal of Analytical Chemistry, 6, 560-568, (2013).

Development and Validation of Spectrophotometric Methods for the Determination of Rasagiline in Pharmaceutical Preparations. Serife Evrim Kepekci Tekkeli, Armagan Önal and Fatemeh Bahadori, Journal of Spectroscopy, doi:10.1155/2013/919180, (2013).

Extractive Spectrophotometric Method for the Determination of Lamivudine and Zidovudine in Pharmaceutical Preparations Using Bromocresol Purple. Serife Evrim Kepekci Tekkeli Journal of Chemistry (2013),doi:10.1155/2013/484389

\section{Other Publications}

Determination of Maprotiline Hydrochloride by Ion-Pair Extraction Using Bromophenol Blue and Bromocresol Purple. Kepekci SE, Oztunç A, Acta Pharmaceutica Turcica, 47 (1), 65-73 (2005).

Effects of Enoant and Ischemia and Reperfusion on Lens Metabolites of Rats. Hülya Güngel, Asiye Nurten, Ehsan Kara, Serife Evrim Kepekci Tekkeli, Elif Özkök and Burçin Yıldız, Analytical Chemistry, doi:10.1155/2013/964601 (2013).

\section{International Conferences and Meetings}

1st European Chemistry Congress, Budapest/Hungary 2006. "SpectrSpectrophotometric Determination of Certain Antidepressants in Pharmaceutical Preparations"

4th Aegean Analytical Chemistry Days, Kuşadası-Aydın/Turkey 2004."Extractive Spectrophotometric Methods for the Determination of Maprotiline in Tablets" 
3th Aegean Analytical Chemistry Days, Lesvos/Greece 2002 "Spectrophotometric Determination of Paroksetine in Tablets Using Bromothymol Blue and Bromocresol Green"

Ulusal Analitik Kimya Kongresi Hatay/2012 “Tabletlerde Eletriptanın Spektrofotometrik Analizi” Kepekci SE, Onal A

Ulusal Spektroskopi Kongresi-Burdur 2013, Development and Validation of Spectrophotometric Methods for the Determination and Spectroscopic Characterization of Vildagliptin using $\pi$-acceptors in Pharmaceutical Preparations, Serife Evrim Kepekci Tekkeli, Armagan Önal and Fatemeh Bahadori

\section{Projects}

A New Spectrophotometric Method for the Determination of Maprotiline- Istanbul University Research Foundation Department- 2003

Development of a new HPLC Method for the Determination of Memantine in Human Plasma and Investigating the Pharmacokinetics of the Drug - Istanbul University Research Foundation Department- 2007

Development of an HPLC-UV method for the analysis of drugs used for combined hypertension therapy in pharmaceutical preparations and human plasma - Bezmialem Vakif University Research Foundation Department -2011

Determiantion of uremic toxins in urine and plasma- Bezmialem Vakif University Research Foundation Department -2011

Determination of biogenic amines- Bezmialem Vakif University Research Foundation Department-2013

\section{Administrative Functions}

Bezmialem Vakif University Faculty of Pharmacy Vice Dean 2012-...

Bezmialem Vakif University Health Sciences Institute Vice Chairman 2010-2012

Bezmialem Vakif University Clinical Trials Ethic Committee Scientific Reporter 2010-...

Bezmialem Vakif University Senate Member 2010- ... 